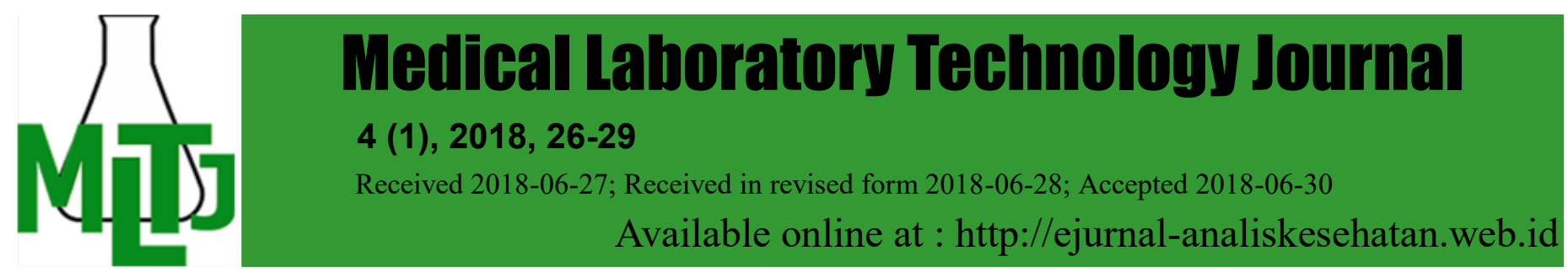

\title{
SPUTUM QUALITY OF THE ANYTIME AND OUTSET FOR EXAMINATION ACID-RESISTANCE BACILLI
}

\author{
Leka Lutpiatina, Wahidah, Nurhilaliah, Dinna Rakhmina, Rifqoh \\ Medical Laboratory Technology Poltekkes Kemenkes Banjarmasin \\ Mistar Cokrokusumo Street 4a Banjarbaru, Indonesia. \\ e-mail: leka.zns@gmail.com
}

\begin{abstract}
Diagnosis Tuberculosis (TB) can establish by microscopic examination of acidresistant bacilli in the patient's sputum. Sputum quality greatly affects the diagnosis of TB, but the sputum collected by patients at community health centers sometimes does not meet the sputum quality requirements. The objective of this study was to assess the quality of sputum anytime and outset sputum on acid-resistant bacilli examination, from volume, color and viscosity parameters. The type of research used is descriptive observational. Respondents were suspected TB patients at the Marabahan and Aluh-aluh Public Health Centers of South Kalimantan province, Indonesia. Sputum samples taken were sputum anytime the first and outset sputum. The variables in this study are volume, color, and viscosity of sputum. The coloring of acidresistant bacilli method Ziehl Nielsen. The results of the acid-resistant bacilli examination on sputum (86 specimens) found positive one (13\%), positive three $(2 \%)$, negative $(85 \%)$. In morning sputum (86 specimens) found positive one (14\%), positive three (2\%), negative (84\%). Sputum quality when with the good category as much as $36 \%$ and the quality of morning sputum with the good category as much as $55 \%$. Conclusion Sputum outset has better quality than sputum at the anytime.
\end{abstract}

Keywords: sputum quality; acid-resistant bacilli

\section{INTRODUCTION}

New tuberculosis cases are generally estimated at 8 million annually (Dye $\mathrm{C}$ et al., 1999). World Health Organization (WHO) stated that the number of new cases of tuberculosis (TB) in 2015 reached 10.4 million people increased from the previous only 9.6 million. India is the country with the largest number of findings of 2.8 million cases. Indonesia as much as 1.02 million cases and China 918 thousand cases. The prevalence of TB patients in Indonesia in 2015 amounted to 395 per 100 population with the mortality rate of 40 per100 thousand population.

Diagnosis Tuberculosis (TB) can establish by microscopic examination of acidresistant bacilli in the patient's sputum. Sputum examination for diagnosis done by collecting three sputum specimens within two consecutive daytime visits of sputum. When the first sputum was collected at the time the TB suspect came for the first time, the morning sputum was sputum collected at home the second morning, immediately after waking up and then the sputum pot was taken and delivered to the service unit, and sputum during the second sputum was collected on the second day, when delivering morning sputum (Kementerian Kesehatan RI.2012).

The results of a correct sputum examination can confirm the diagnosis of TB; it can achieve by taking into account: time of specimen collection, specimen collection site, specimen collection method, specimen quality, preparation method, availability of tools and materials, supporting facilities and reading skill. Taking note and recording the quality of the specimens obtained is one of the important things in microscopic TB examination because it is suspected to be related to the amount of BTA germs found in the examination. The quality of the sputum specimen consists of volume 3-5ml, viscosity (thick / dilute), color (yellow/green/redness) (Kementerian Kes RI. 2012). 
Sputum quality greatly affects TB diagnostic outcomes, but the sputum collected by patients at public health centers sometimes does not qualify for sputum quality, from volume, color, and viscosity. It is important to assess the quality of sputum during the morning, when used in the acid-resistant bacilli examination, so that the results of the laboratory examination to enforce the diagnosis of tuberculosis become more valid. The purpose of this study was to assess the quality of sputum anytime and outset sputum on acid-resistant bacilli examination of volume, color and viscosity parameters.

\section{MATERIAL AND METHODE}

The type of research used is descriptive observational. Respondents were suspect TB outpatients at the Marabahan and Aluh-aluh Public Health Centers in South Kalimantan, Indonesia. Sputum samples taken were sputum anytime the first sputum was collected at the time of suspected TB coming to the first visit. And sputum that outset sputum coughed at home the second morning, immediately after waking up and sputum pots delivered to the service unit.

The variables in this study are sputum color (Appropriate: White, like milk (mucoid), Yellow / dark yellow (mucopurulent), Light Green / Dark Green (Purulent), Red (bleeding) Not Appropriate: colors other than good quality criteria , sputum volume (Appropriate: if sputum volume 3-5 ml. Not Appropriate: if sputum volume $<3 \mathrm{ml}$ ) and viscosity of sputum). Appropriate sputum viscosity: thick (if sputum lifted with a stick). Not Appropriate: not thick / dilute (if sputum not lifted with a stick).

The laboratory officer has directed the patient to remove the sputum correctly. Assessment of the patient's sputum from volume, color, and viscosities. Preparation of sputum removal by using a stick on the object glass with small spiral strokes. The preparations fixed and acid-resistant bacilli dyeing of Ziehl Neelsen method using Carbol Fuchsin $0.3 \%$, $\mathrm{HCl}-A$ lcohol 3\%, Methylene Blue 0.3\%. Assessment of microscopic examination of acidresistant bacilli based on the presence or absence of acid-resistant bacilli. The degree of positivity in assessing the results of microscopic acid-resistant bacilli examination can use according to the International Union Against Tuberculosis and Lung Disease (IUATLD).

\section{RESULTS AND DISCUSSION}

Table 1 Sputum Inspection Result Based on Sputum Volume on Suspect Tuberculosis

\begin{tabular}{|c|c|c|c|c|}
\hline \multirow{3}{*}{ Sputum Volume } & \multicolumn{4}{|c|}{ Sputum Examination Results } \\
\hline & \multicolumn{2}{|c|}{ Anytime } & \multicolumn{2}{|c|}{ Outset } \\
\hline & Frequency & $\%$ & Frequency & $\%$ \\
\hline $\begin{array}{l}\text { Appropriate } \\
(3-5 \mathrm{ml})\end{array}$ & 42 & 49 & 48 & 56 \\
\hline $\begin{array}{l}\text { Not Appropriate } \\
(<3 \mathrm{ml})\end{array}$ & 44 & 51 & 38 & 44 \\
\hline Total & 86 & 100 & 86 & 100 \\
\hline
\end{tabular}

Table. 2 Sputum examination Result Based on Sputum Colors On Tuberculosis Suspects

\begin{tabular}{lllll}
\hline & \multicolumn{3}{c}{ Sputum Examination Results } \\
Sputum Color & \multicolumn{2}{c}{ Anytime } & \multicolumn{2}{c}{ Outset } \\
& Frequency & $\%$ & Frequency & $\%$ \\
\hline Appropriate & 31 & 36 & 52 & 60 \\
Not Appropriate & 55 & 64 & 34 & 40 \\
Total & 86 & 100 & 86 & 100 \\
\hline
\end{tabular}

Table. 3. Sputum Examination Result Based on Sputum Viscosity In Tuberculosis Suspects

\begin{tabular}{|c|c|c|c|c|}
\hline \multirow{3}{*}{ sputum viscosity } & \multicolumn{4}{|c|}{ Sputum Examination Results } \\
\hline & Anytime & & Outset & \\
\hline & Frequency & $\%$ & Frequency & $\%$ \\
\hline Appropriate & 31 & 36 & 52 & 60 \\
\hline Not Appropriate & 55 & 64 & 34 & 40 \\
\hline Total & 86 & 100 & 86 & 100 \\
\hline
\end{tabular}

The quality of sputum-based on the volume, color and viscosity categories can summarize in the following table:

Table. 4 The quality of sputum-based on the volume, color and viscosity categories

\begin{tabular}{lcccc}
\hline sputum quality & \multicolumn{4}{c}{$\begin{array}{c}\text { Sputum Examination Results } \\
\text { Anytime }\end{array}$} \\
& Frequency & $\%$ & Frequency & $\%$ \\
\hline Appropriate & 31 & 36 & 47 & 55 \\
Not Appropriate & 55 & 64 & 39 & 45 \\
Total & 86 & 100 & 86 & 100 \\
\hline
\end{tabular}


Table 5. Microscopic examination results of acid-resistant bacilli Sputum on Tuberculosis Suspects

\begin{tabular}{lcccc}
\hline & \multicolumn{4}{c}{$\begin{array}{c}\text { Microskopis Sputum Examination } \\
\text { Results Acid-Resistant Bacilli } \\
\text { Degradasi Value }\end{array}$} \\
& $\begin{array}{c}\text { Anytime } \\
\text { Frequency }\end{array}$ & $\begin{array}{c}\text { Outset } \\
\text { Frequency }\end{array}$ & $\%$ \\
\hline Negative & 73 & 85 & 72 & 84 \\
Scanty & 0 & 0 & 0 & 0 \\
Positive 1 (+) & 11 & 13 & 12 & 14 \\
Positive 2 (++) & 0 & 0 & 0 & 0 \\
Positive 3(+++) & 2 & 2 & 2 & 2 \\
\hline Total & 86 & 100 & 86 & 100 \\
\hline
\end{tabular}

Based on the results of the research table 5 can be seen that the results of sputum quality anytime lower $(36 \%)$. The outset sputum shows good quality is higher $(55 \%)$. In the morning the patient is easier to remove sputum because at night enough rest and less activity. Anatomical abnormalities of pulmonary tuberculosis located in the lobule parenchyma, including alveoli and some terminal bronchioles, consolidation, and secretion in bronchioles. This process causes secretions to collect when the patient slept and expelled when the patient wakes up in the morning. According to the Ministry of Health of 2012, the best Sputum is usually the sputum obtained when the patient wakes up early, the patient should rinse or brush his teeth first before coughing sputum.

Sputum that qualifies the examination must be completely out of trachea or bronchi, not saliva from the mouth. According to Chang KC 2008 Hadley M and Maher D 2000, Sputum can collect by various methods ranging from sputum induction and physiotherapy to more invasive procedures such as bronchoalveolar lavage.

Ministry of Health of the Republic of Indonesia in Training Module Inspection of Microscopic Sputum TB gives guidance to get a quality specimen, patient to rinse with water before removing sputum. When wearing dentures, remove them before rinsing. Breathe in 2-3 times and each time breath out strongly. The opened pot placed close to the mouth, and the sputum is ejected into the cup by being coughed loudly from inside the chest. Cup closed tightly by turning the lid. After removing the sputum, the mouth cleaned with a tissue, then the tissue is thrown in a covered bin, then wash the hands. Can be repeated until it gets good quality sputum and sufficient volume (3-5 $\mathrm{ml}$ ). If sputum is difficult to remove, it can do as follows do mild exercise then take a few breaths. When it feels coughing, breath is held for as long as possible and then told to cough. The night before bed, drink plenty of water or swallow one tablet of glyceryl guayakolat 200 $\mathrm{mg}$.

In this study, community health center officers have given clear directions to patients before sputum collection. However many sputum quality results do not match the standards. This is also likely from the condition of patients who do not understand how to remove sputum well. According to Bell DJ, Dacombe R, Graham SM, et al. 2009 patient education, training of health workers and community involvement play a role in TB programs.

Sakundarno et al. showed similar results, i.e., only $45 \%$ good quality sputum. According to Sakundarno et al. 2009, A sputum collection with direct guidance and supervision of the patient at the expense of sputum is useful for obtaining good quality sputum specimens (not just saliva).

The quality of sputum volume from Table 1 shows the dominant results in the bad categorical. The quality of sputum collected $\mathrm{Pa}$ tients many do not conform to the standard (volume $<3 \mathrm{ml})$. According to the microscopic tubercolusis microscopic examination of the sputum volume requirement of 3-5 ml. Lack of sputum volume is likely to affect the results of smear examination. Even according to Iqbal Rashid 2011, sputum with $5 \mathrm{ml}$ volume has a higher sensitivity than $2 \mathrm{ml}$ volume. Other researchers have suggested a $5 \mathrm{ml}$ sputum volume to detect BTA in the diagnosis of pulmonary tuberculosis (Warren JR 2000, Parry CM 1995, Gupta KB and Garg S 2005).

The color quality and consistency of sputum from tables $2 \& 3$ show the dominant result in the bad category. This shows that the sputum collected is much saliva. Although salivary results are found to be positive, they tend to be low positive, so it not recommended for diagnosis because of the chances of finding acid-resistant bacilli in smaller salivary specimens. Several literatures indicate that specimens containing only saliva should be examined although the likelihood of a positive outcome is low (Misnadiarly, 2006). 
Table 5 showed more positive $1(+)$ results from outset sputum $(14 \%)$ than sputum anytime (13\%). The data indicate that there is a difference of acid-resistant bacilli-acid and acid-resistant bacilli-in acid-resistant bacilliacid results in the same patient. According to Ari Handoko (2013), There is a significant relationship between the quality of sputum and gradation of acid-resistant bacilli examination results. Good quality sputum can lead to a decrease in the value of gradation and even make a false negative result.

The study conducted at a community health center, a sample of sputum issued by the patient directly at a local laboratory check, so that the sputum sample storage time is less than 1 hour. The literature states sputum can be stored safely in the refrigerator $\left(4^{\circ} \mathrm{C}\right)$ for eight weeks without affecting the positive yield of acid-resistant bacilli (Banda HT 2004). Immediate work on sputum samples also avoids contamination of the external environment. According to Maciel EL 2009 contamination specimens can be caused by a container and room specimens laid before reaching the laboratory.

\section{CONCLUSION}

Sputum quality anytime with a right category as much as $36 \%$ and the quality of outset sputum with the good category as much as $55 \%$. Sputum morning has better quality.

\section{REFERENSI}

Handoko, A., Aminah, S., \& Marhamah. (2013). Hubungan Kualitas Spesimen Sputum Dengan Gradasi Hasil Pemeriksaan BTA Pada Penderita TB Paru Di Kabupaten Pringsewu Tahun 2012. Jurnal Analis Kesehatan, 2(2).

Banda HT, Harries AD, Boeree MJ, et al. (2000). Viability of stored specimens for smear microscopy and culture. Int $J$ Tuberc Lung Dis, 4(3), 272-274.

Bell DJ, Dacombe R, Graham SM, et al. (2009). Simple measures are as effective as invasive techniques in the diagnosis of pulmonary tuberculosis in Malawi. Int $J$ Tuberc Lung Dis., 13(1), 99-104.

Chang KC, Leung CC, Yew WW, Tam. C. M. (2008). Supervised and induced sputum among patients with smear-negative pulmonary tuberculosis. Eur Respir J., 31, 1085-1090.

Dye C, Scheele S, Dolin P, Pathania V, Ravi- glione M. (1999). Global burden of tuberculosis: estimated incidence, prevalence, and mortality by country: WHO global surveillance and monitoring project. JAMA, 282, 677-686.

Gupta KB and Garg S. (2005). Use of sputum induction for establishing diagnosis in suspected pulmonary tuberculosis. Indian $J$ Tuberc, 52, 143-146.

Hadley, M., \& Maher, D. (2000). Community involvement in tuberculosis control: lessons from other health care programmes. Int J Tuberc Lung Dis, 4(5), 401-408.

Rashid, I., Hangalibalele L., Mabuza, Govender, I., \& Pretorius, D. (2011). Volume of sputum to detect acid-fast bacilli as a measure of quality for the diagnosis of pulmonary tuberculosis at the Dr George Mukhari Hospital, South Africa. PHCFM African Journal of Primary Health Care \& Family Medicine, 3(1).

Maciel EL, Prado TN, Peres RL, Palaci M, Johnson JL, Dietze R. (2009). Guided sputum sample collection and culture contamination rates in the diagnosis of pulmonary TB. J Bras Pneumol, 35(5), 460-463.

Misnadiarly. (2006). Tuberkulosis dan Mycobacterium Atipik. Jakarta: Dian Rakyat.

Kementerian Kesehatan RI. (2012). Modul Pelatihan Pemeriksaan Sputum Mikroskopis TB. Jakarta: Direktorat Jenderal Bina Upaya Kesehatan.

Parry CM, Kamoto O, Harries AD, Wirima JJ, Nyirenda CM, Nyangulu DS, et al. (1995). The use of sputum induction for establishing a diagnosis in patients with suspected pulmonary tuberculosis in Malawi. Tuber Lung Dis, 76(1), 72-76.

Sakundarno $M$, Nurjazuli $N$, Jati $S P$, et al. (2009). Insufficient quality of sputum submitted for tuberculosis diagnosis and associated factors, in Klaten district, Indonesia. BMC Pulm Med, 9(1), 16-26

Warren JR, Bhattacharya M, De Almeida KNF, Trakas K, Peterson LR. (2000). A minimum $5.0 \mathrm{~mL}$ of sputum improves the sensitivity of acid-fast smear for mycobacterium tuberculosis. Am J Respir Crit Care Med., 161, 1559-1562. 